\title{
Life cycle assessment of milk production from commercial dairy farms: The influence of management tactics
}

\author{
M.-J. Yan, ${ }^{*}$ J. Humphreys, $†$ and N. M. Holden* ${ }^{1}$ \\ *School of Biosystems Engineering, University College Dublin, Belfield, Dublin 4, Dublin, Ireland \\ †Animal and Grassland Research and Innovation Centre, Teagasc, Moorepark, Fermoy, Co. Cork, Ireland
}

\begin{abstract}
Little consideration has been given to how farm management, specifically tactics used to implement the management strategy, may influence the carbon footprint $(\mathrm{CF})$ and land use for milk produced on commercial farms. In this study, the $\mathrm{CF}$ and land use of milk production from 18 Irish commercial dairy farms were analyzed based on foreground data from a 12-mo survey capturing management tactics and background data from the literature. Large variation was found in farm attributes and management tactics; for example, up to a 1.5-fold difference in fertilizer nitrogen input was used to support the same stocking density, and up to a 3.5-fold difference in concentrate fed for similar milk output per cow. However, the coefficient of variation for milk CF between farms only varied by $13 \%$ and for land use by $18 \%$. The overall $\mathrm{CF}$ and overall land use of the milk production from the 18 dairy farms was $1.23 \pm 0.04 \mathrm{~kg}$ of $\mathrm{CO}_{2} \mathrm{Eq}$ and $1.22 \pm$ $0.05 \mathrm{~m}^{2}$ per kilogram of energy-corrected milk. Milk output per cow, economic allocation between exports of milk and liveweight, and on-farm diesel use per ha were found to be influential factors on milk CF, whereas the fertilizer $\mathrm{N}$ rate, milk output per cow, and economic allocation between exports of milk and liveweight were influential on land use. Effective sward management of white clover within a few farms appeared to lower the $\mathrm{CF}$ but increased on-farm land use. It was concluded that a combination of multiple tactics determines $\mathrm{CF}$ and land use for milk production on commercial dairy farms and, although these 2 measures of environmental impact are correlated, a farm with a low CF did not always have low land use and vice versa.
\end{abstract}

Key words: management tactics, carbon footprint, land use, milk production

Received September 9, 2012.

Accepted March 24, 2013.

${ }^{1}$ Corresponding author: nick.holden@ucd.ie

\section{INTRODUCTION}

It is now accepted that anthropogenic greenhouse gas (GHG) emissions are contributing to global climate change (Solomon et al., 2007). The global dairy sector was estimated to contribute $4 \%$ of anthropogenic GHG emissions (Gerber et al., 2010). Due to projected population growth and demand for dairy products (Steinfeld et al., 2006), urgent action is needed to balance profitability and environmental impact of dairy production. In Europe, the expiration of milk quotas in 2015 has set an encouraging signal for milk production, where the system has low cost and high economic competitiveness (e.g., Ireland). Increased production may require more on-farm land for grazing or prefarm land for feed production. Because increasing demand for animal feed demand tends to cause deforestation and contribute to GHG emissions (Cederberg et al., 2011), it is necessary to understand the influential factors on land use of milk production.

Life cycle assessment (LCA) has been used to analyze the environmental impact associated with agricultural production (e.g., Cederberg and Mattsson, 2000; Casey and Holden, 2005a), post-farm phases (e.g., packaging; Humbert et al., 2009), and final products (Nilsson et al., 2010). The LCA interpretation of GHG emissions is also referred to as the carbon footprint $(\mathbf{C F})$. Agricultural production has been found to dominate the impacts of dairy products, particularly fresh milk (IDF, 2009). Life cycle assessment of milk production is usually modeled without consideration of mechanistic interactions [Del Prado et al. (2011) being a notable exception], and with a focus on descriptive inventories compiled from either census statistics [e.g., Thomassen et al., 2009 (119 farms); Henriksson et al., 2011 (1,051 farms)], or ad hoc farm surveys [e.g., Casey and Holden, 2005a (10 farms); van der Werf et al., 2007 (47 farms); Kristensen et al., 2011 (67 farms)]. Life cycle assessment using ad hoc survey data can provide a detailed picture of each farm but normally reflect a static view of the farms (i.e., annual totals for activity), whereas census statistics can mask detail of interfarm variations that may be important for interpretation. 
The main focus of previous LCA studies on milk has been on mode of production (e.g., organic vs. conventional; Yan et al., 2011). However, large variation among individual farms has often been found (Henriksson et al., 2011) and it has been suggested that this could be more significant than differences between modes of production (van der Werf et al., 2007). Little consideration has been given to how farm management, specifically tactics used to implement the management strategy, may influence $\mathrm{CF}$ and land use of commercial farms. Combinations of management tactics (e.g., stocking rate, manure and fertilizer management, concentrates fed, output per cow, and housing schedules) are used by farmers to adopt a general strategy (e.g., rotational grazing of permanent grassland) to their own circumstances. In Ireland, agriculture is the largest contributor to overall GHG emissions at 26\% (McGettigan et al., 2010) and occupies over $60 \%$ of the land area (Department of Agriculture, Fisheries and Food, 2011), and grassland-derived milk accounts for around $29 \%$ of the gross economic output of the sector (Department of Agriculture, Fisheries and Food, 2011). It has been estimated that the CF of Irish milk could vary between 1.0 to $1.3 \mathrm{~kg}$ of $\mathrm{CO}_{2} \mathrm{Eq} / \mathrm{kg}$ of ECM (Casey and Holden, 2005b; Weiss and Leip, 2012), but little consideration has been given to whether detail of tactical management has an influence on the specific $\mathrm{CF}$ and land use of a given farm. Mitigation strategies such as change in sward management by substituting mineral $\mathrm{N}$ with white clover-derived $\mathrm{N}$ was found to not only provide economic benefit (Humphreys et al., 2012), but also has the potential to significantly reduce milk $\mathrm{CF}$ at research farm scale (Schils et al., 2006; Basset-Mens et al., 2009) but it remains unclear whether such an impact remains when subject to the differences in farm management that occur on commercial dairy farms.

The specific objective of this work was to evaluate whether the farms, all of which use the same general strategic management (i.e., rotational grazing of permanent grassland), were likely to be producing milk with a similar $\mathrm{CF}$ and land use. We hypothesize that the detail of the management tactics is an important driver of differences between farm environmental impact, as indicated by $\mathrm{CF}$ and land use.

\section{MATERIALS AND METHODS}

In this study, a farm survey was conducted using monthly site visits to build a detailed picture of farm activity throughout the year. These data were used to compile the farm inventory for the LCA analysis and, in this way, details of the management tactics were captured. The LCA model was developed using a spreadsheet, and the 4 stages of LCA methodology (goal and scope definition, life cycle inventory, life cycle impact assessment, and results interpretation) have been implemented according to the International Organization for Standardization (ISO, 2006). During the study, a 12-mo farm survey was carried out from January to December 2010 by a technician who visited 21 farms every month and collected data on farm management for the previous month. Issues of fact and possible error were identified shortly afterward. Subsequently data were compared for validation with data collected from the Teagasc Profit Monitor program (Teagasc, 2011), legal documents supplied by the farmer for the land area, and processor records of milk sales. In cases where nonresolvable discrepancies arose, reanalysis or clarification with the farmer resolved the issues or the farm was excluded from analysis. Of the 21 dairy farms surveyed, 3 were excluded due to nonresolvable inconsistencies relating to missing records of milk sale, the presence of an additional beef herd, and uncertainty about the proportion of the farm used for nondairy activity. The sample of 18 farms represented about $0.14 \%$ of full-time dairy farms in Ireland (Hennessy et al., 2011), and were located in the south and east of Ireland, where dairying is an important agricultural activity.

\section{Goal and Scope}

In the goal and scope phase, the production system is described, a functional unit (FU; to which all subsequent inputs and outputs are related) and system boundary (which determines the processes associated with the delivery of the FU) are defined, and in the case of a multiproduct system, the allocation procedure between products is specified (ISO, 2006). The goal was to calculate the $\mathrm{CF}$ and land use of milk produced by a small number of specialized dairy farmers in Ireland over a 12-mo period to establish the influence of their management tactics on $\mathrm{CF}$ and land use calculated by LCA. The FU was defined as $1 \mathrm{~kg}$ of ECM delivered at the farm gate in 1 yr (Sjaunja et al., 1990), and the reference flow was expressed as follows:

$$
\mathrm{ECM}=\text { milk delivered } \times(0.25+0.122
$$

$\times$ fat percentage $+0.077 \times$ protein percentage).

The system boundary was cradle-to-farm gate, including the foreground processes of milk production on the farm and the background processes of production and transportation of synthetic fertilizers; cultivation, processing, and transportation of concentrate feed; and production and use of electricity and diesel fuels and seeds for reseeding. Infrastructure (sheds, slurry lagoon, and roads), machinery (tractors and milk cooling sys- 
tems), medicines, refrigerant for milk cooling, pesticides, udder disinfectant, and disposal of silage plastic were not included due to lack of data. All farms were selfsufficient with regard to manure management except 2 that imported or exported small amounts of slurry $(<200$ $\mathrm{m}^{3}$ ). Greenhouse gas emissions associated with manure spreading were included or excluded accordingly. Soil carbon sequestration was not quantified because of the lack of suitable site-specific data and due to a lack of consensus on the effect of conventional and minimum tillage on carbon sequestration (Luo et al., 2010).

Allocation was required for 2 multi-production processes in the model: between concentrate feed ingredients and co-products (prefarm) and between milk and co-products from the farm (on farm). Economic allocation for concentrate feed is commonly used (Yan et al., 2011) and recommended by the International Dairy Federation (IDF, 2010). Data on sugar and oil co-products (rape meal, palm kernel meal, and molasses) were allocated by the Ecoinvent 2.2 database (Ecoinvent, 2011), whereas soybean hulls and maize gluten meal were derived from Ecoinvent 2.2 data sets and allocated according to Thomassen et al. (2008) and Cederberg and Mattsson (2000), respectively.

Allocation between milk and co-products on farm was done in 2 steps. The first step was allocation between dairy unit and other enterprise. This was necessary because the farmers, despite specializing in dairy production, operated additional enterprises on the farm, typically rearing of dairy heifers for sale, and the monthly survey was on a whole-farm basis. In other studies, system expansion has been used to account for multiple enterprises on one farm (Cederberg and Stadig, 2003; Flysjö et al., 2012), but it could not be used in the current study due to uncertainty about the fate of the animals sold off the dairy farms and, hence, the avoided burden that occurred. The division of impact between the dairy unit and other enterprises was considered allocation, because the other enterprises generally derived from the dairy herds (e.g., bull calves and surplus heifers) rather than standing alone, shared use of land, sheds, and manure tanks with the dairy herd. The second step was economic allocation between milk and liveweight export (surplus female calves, bulls, replacement animals, and culled cows) from the dairy unit based on the farm sales records. This approach has been used before but with amount of meat rather than liveweight (Flysjö et al., 2011; Kristensen et al., 2011). As the sales records did not reveal the fate of the animal sold, it was decided to use liveweight to reduce uncertainty. The allocation steps were as follows:

a. Convert all animal records into livestock unit (LU) equivalence based on the ratio of nitrogen excretion compared with a typical dairy cow, as defined by Statutory Instruments (S.I.) No. 610 (European Communities, 2010; pages 38-39):

$$
\mathrm{LU}_{\mathrm{T}}=\Sigma \mathrm{LU}_{\mathrm{i}} \times \mathrm{n}_{\mathrm{i}},
$$

where $\mathrm{LU}_{\mathrm{T}}=$ total $\mathrm{LU}$; $\mathrm{LU}_{\mathrm{i}}=\mathrm{LU}$ of animal of type i, where i can be dairy cow, dry cow, calf, or bull; and $n_{i}=$ number of animals of type $i$.

b. Calculate the LU of the dairy unit, which consisted of dairy cows, replacements (0- to 1- and 1- to 2-yr-old females), and bulls (if any):

$$
\mathrm{LU}_{\mathrm{DU}}=\mathrm{LU}_{\mathrm{C}}+\mathrm{LU}_{\mathrm{R}}+\mathrm{LU}_{\mathrm{B}},
$$

where $\mathrm{DU}=$ dairy unit, $\mathrm{C}=$ cows, $\mathrm{R}=$ replacement animals, and $\mathrm{B}=$ bulls.

c. Allocation between dairy unit and other farm activities:

$$
\mathrm{AF} 1=\mathrm{LU}_{\mathrm{DU}} / \mathrm{LU}_{\mathrm{T}},
$$

where AF1 stands for allocation factor (AF) 1.

d. Exclude electricity from the farm GHG inventory because it is predominantly used for dairy production (i.e., milk cooling), calculate the proportion of farm activity attributable to the dairy production, and then add back the electricity to estimate GHG associated with the dairy unit $\left(\mathrm{GHG}_{\mathrm{DU}}\right)$ :

$\mathrm{GHG}_{\mathrm{DU}}=\left[\left(\mathrm{GHG}_{\mathrm{T}}-\mathrm{GHG}_{\mathrm{E}}\right) \times \mathrm{AF} 1\right]+\mathrm{GHG}_{\mathrm{E}},[5]$

where $\mathrm{GHG}_{\mathrm{T}}=$ total GHG of the farm activities (from cradle to farm gate; $\mathrm{kg}$ of $\mathrm{CO}_{2} \mathrm{Eq}$ ) and $\mathrm{GHG}_{\mathrm{E}}=\mathrm{GHG}$ emissions of electricity production ( $\mathrm{kg}$ of $\left.\mathrm{CO}_{2} \mathrm{Eq}\right)$.

e. Allocation between milk and meat from surplus calves, culled cows, and bulls (if any) was performed based on the farm sales record collected during the survey:

$$
\mathrm{GHG}_{\mathrm{Milk}}=\mathrm{GHG}_{\mathrm{DU}} \times \mathrm{AF} 2,
$$

where $\mathrm{GHG}_{\mathrm{Milk}}=\mathrm{GHG}$ attributed to the milk produced from cradle to farm gate $\left(\mathrm{kg}\right.$ of $\mathrm{CO}_{2}$ Eq) and AF2 (allocation factor 2) = milk sale/ dairy unit sale.

A similar procedure was applied to LU:

$$
\text { Land }_{\text {Milk }}=\left(\text { Land }_{\text {on-farm }}+\text { Land }_{\text {prefarm }}\right) \times \mathrm{AF} 1 \times \mathrm{AF} 2 \text {. }
$$

Instead of the 2-step allocation mentioned above, alternative allocation can be done solely based on milk sales as a proportion of total farm sales: 


$$
\begin{gathered}
\mathrm{GHG}_{\text {Milk }}=\mathrm{GHG}_{\mathrm{T}} \times \mathrm{AF} 3 ; \\
\text { Land }_{\text {Milk }}=\left(\text { Land }_{\text {on-farm }}+\text { Land }_{\text {prefarm }}\right) \times \mathrm{AF} 3,
\end{gathered}
$$

where AF3 (allocation factor 3) = milk sales/total farm sales.

\section{Life Cycle Inventory}

In the life cycle inventory phase, all input and output processes are defined and quantified (ISO, 2006). The GHG inventory was made by multiplying life cycle activity data by emission factors (EF) derived from the literature. To estimate the milk output per cow, the total milk produced in 1 yr was divided by the average number of milking cows during the main production season (i.e., May to September) and adding $301 \mathrm{~kg} /$ cow to account for calf consumption (O'Mara, 2006). Enteric $\mathrm{CH}_{4}$ from cows was determined by estimating $\mathrm{NE}_{\mathrm{M}}, \mathrm{NE}_{\mathrm{L}}$, and net energy (NE) for pregnancy (Shalloo et al., 2004; O'Mara, 2006). The NE of grazed pasture was calculated as the difference between NE intake from silage (both made on farm and purchased) plus concentrate and that needed to meet the total NE requirements (Humphreys et al. 2008). The NE of feed was then converted into DMI and multiplied by the EF for enteric fermentation of $21.6 \mathrm{~g}$ of $\mathrm{CH}_{4} / \mathrm{kg}$ of DMI (O'Mara, 2006). Enteric $\mathrm{CH}_{4}$ from nondairy animals and $\mathrm{CH}_{4}$ emissions from manure management of all animals were estimated using national average EF based on Intergovernmental Panel on Climate Change (IPCC) Tier 2 methods (McGettigan et al., 2010).

Direct $\mathrm{N}_{2} \mathrm{O}$ emissions from manure management and soils were estimated according to McGettigan et al. (2010) but with EF of 1\% (IPCC, 2006). The N excretion rate for each type of animal, and $\mathrm{N}$ content and availability of manure were taken from S.I. No. 610 (European Communities, 2010; pages 38-39), and $93.75 \%$ of the stored $\mathrm{N}$ was assumed to be slurry and the rest farm yard manure (McGettigan et al., 2010). Indirect $\mathrm{N}_{2} \mathrm{O}$ emissions from atmospheric deposition and leaching were estimated using IPCC Tier 2 methods, where $1 \%$ of $\mathrm{NH}_{3}$ and mononitrogen oxide $\left(\mathrm{NO}_{\mathrm{X}}\right)$ emissions and $0.25 \%$ of $\mathrm{N}$ input to soils were assumed to be reemitted as $\mathrm{N}_{2} \mathrm{O}$ (McGettigan et al., 2010).

Greenhouse gas emissions for field activities (e.g., silage cut) were taken from the Ecoinvent 2.2 database (Ecoinvent, 2011). Emissions from the concrete yard were not included due to their very low contribution (Casey and Holden, 2005b). Carbon dioxide emissions from lime spreading were estimated with IPCC Tier 1 (IPCC, 2006), whereas the $\mathrm{CO}_{2}$ emissions from urea spreading were excluded because the $\mathrm{CO}_{2}$ consumption during urea production was not included in the Ecoinvent 2.2 database (Nemecek et al., 2007).

Background emissions from production of fertilizer components (calcium ammonium nitrate, urea, and lime) were taken from the Ecoinvent 2.2 database (Ecoinvent, 2011) because fertilizer manufacture in Ireland no longer takes place and all fertilizers are either imported as finished products or undergo further blending only (McGettigan et al., 2010). Emissions from production of compound fertilizers (N-P-K) were approximated using the building blocks of calcium ammonium nitrate, urea, diammonium phosphate, and potassium chloride, which are the most commonly used fertilizer components in Ireland (S. Lalor, Teagasc Johnstown Castle, Ireland, personal communication). In the case of zero nitrogen (0-7-30 N-P-K), triple superphosphate was assumed instead of diammonium phosphate. The blending assumption could be an underestimation because fillers (inert salts) and micronutrients were excluded and can represent up to $33 \%$ of the total mass (e.g., 8-5-18; S. Lalor, TeagascTeagasc Johnstown Castle, Ireland, personal communication) and the GHG emissions from the blending processes and production of micronutrients were not included due to lack of data.

A standard concentrate formulation was obtained from several feed suppliers and data sets regarding producing and processing relevant ingredients were selected from the Ecoinvent 2.2 database to calculate the GHG emissions, including those from land use change (Ecoinvent, 2011). The GHG emissions of concentrate production were found to be $66 \%$ lower than those of Casey and Holden (2005a) due to differences in assumed ingredients and sources of data. Emissions associated with electricity use on farm were taken from Irish energy reports as $0.533 \mathrm{~kg}$ of $\mathrm{CO}_{2} \mathrm{Eq} / \mathrm{kWh}$ in 2010 (SEAI, 2010), which was considered more reliable than the $0.216 \mathrm{~kg}$ of $\mathrm{CO}_{2} \mathrm{Eq} / \mathrm{kWh}$ from the Ecoinvent v 2.2 database (Ecoinvent, 2011). All transportation was assumed to start from the origin (fertilizer from Germany, lime from local quarries, and concentrates from various places) and as necessary through overseas freight ship to Rotterdam (the Netherlands), barge tanker to Dublin (Ireland), and lorry [ $>32$ t; European emission standard 3 (Euro 3)] to farms. The inventory of land use was compiled by adding up both the on-farm agricultural land area from farm survey and prefarm land area for feed production estimated by data sets in the Ecoinvent 2.2 database (Ecoinvent, 2011).

\section{Life Cycle Impact Assessment}

In the life cycle impact assessment stage, the inventory is linked to specific environmental impact catego- 
ries and indicators (ISO, 2006). Carbon footprint and land use were analyzed in this study. To express the carbon footprint, a commonly used indicator is global warming potential, defined in a time frame of $100 \mathrm{yr}$, with characterization factors of 25 and $298 \mathrm{~kg}$ of $\mathrm{CO}_{2}$ $\mathrm{Eq} / \mathrm{kg}$ for $\mathrm{CH}_{4}$ and $\mathrm{N}_{2} \mathrm{O}$ (Solomon et al., 2007). Milk $\mathrm{CF}$ ( $\mathrm{kg}$ of $\mathrm{CO}_{2} \mathrm{Eq}$ ) was calculated as follows:

$$
\text { Milk } \mathrm{CF}=\mathrm{GHG}_{\mathrm{Milk}} / \mathrm{ECM} \text {. }
$$

All types of land use were assigned the same characterization factor of $1 \mathrm{~m}^{2} / \mathrm{m}^{2}$ (Guinée et al., 2002). Land use per unit milk was estimated as follows:

$$
\text { Land use }=\operatorname{Land}_{\text {Milk }} / \text { ECM. }
$$

\section{Interpretation}

Interpretation of life cycle impact assessment consists of identifying significant issues, evaluation of the model, and making conclusions (ISO, 2006). Geographical origin of emissions (i.e., within or outside Ireland) and major contributing processes to $\mathrm{CF}$ and land use from milk production by the 18 commercial farms were specified. Stepwise linear regression (PASW Statistics 18,2012 ) was performed to identify the contribution of management tactics (e.g., milk output per cow and stocking rate) to $\mathrm{CF}$ and land use; K-means clustering was used to group farms based on influential tactics so as to see difference among farms and the effect on $\mathrm{CF}$ and land use. Differences between clusters were analyzed and presented by one-way ANOVA (PASW Statistics 18, 2012). Assumptions used in LCA modeling were evaluated and correlation between CF and land use and mitigation strategies were discussed.

\section{RESULTS}

\section{Milk CF}

The overall $\mathrm{CF}$ of the milk produced by the dairy farms in 2010 was $1.23 \pm 0.04 \mathrm{~kg}$ of $\mathrm{CO}_{2} \mathrm{Eq} / \mathrm{kg}$ of ECM, $80 \%$ of which derived from on-farm activities. The annual average milk output of the 18 farms was $5,700 \mathrm{~kg} / \mathrm{cow}, 10 \%$ higher than the national average in the same year (CSO, 2010a,b,c). The average fertilizer $\mathrm{N}$ rate was $205.3 \mathrm{~kg}$ of $\mathrm{N} / \mathrm{ha}$ and was higher than the national level in 2008 (134 kg of N/ha; Lalor et al., 2010). The average concentrate supplemented was $958 \mathrm{~kg} / \mathrm{cow}$ and was higher than a previous estimation of the national average (789 kg/cow; O'Mara, 2006). On average, $94 \%$ of the LU on farm were dairy cattle and the remainder were beef cattle (one farm kept $5 \%$ sheep). Within the dairy unit, $87 \%$ of sales came from milk, $8 \%$ from cows, $5 \%$ from calves and replacement animals, and a negligible amount $(0.1 \%)$ from bulls. The age of the milking system (13 modern and 4 older) did not influence the electricity use per kilogram of milk. There was large variation among farms (Table 1) in terms of attributes (e.g., land area and number of cows) and management tactics (e.g., milk output per cow and fertilizer per hectare). For example, as much as 1.5 times higher fertilizer input was found to support the same stocking density, and up to a 3.5-fold difference in concentrate feed to gain a similar milk output per cow. The contributions to $\mathrm{CF}$ were dominated by enteric fermentation (43\%), followed by excreta deposition and fertilizer spreading (both 11\%), manure storage and fertilizer production (both 10\%), concentrate feed production (6\%), manure spreading (4\%), electricity and diesel production (3\%), and diesel combustion in field work and transportation (both 1\%).

Three out of the 9 main tactics (milk output per cow, concentrate per cow, AF1, AF2, on-farm diesel use per hectare, kilowatt hours of electricity per kilogram of ECM, stocking rate, fertilizer nitrogen rate, and white clover seed density) were found by stepwise regression to be possible indicators of milk $\mathrm{CF}$ :

$$
\begin{aligned}
\text { Milk CF } & =0.70-1.39 \times 10^{-4} \mathrm{M}_{\mathrm{C}}+1.25 \times \mathrm{AF} 2 \\
& +5.85 \times 10^{-3} \mathrm{D}\left(\mathrm{R}^{2}=0.85\right),
\end{aligned}
$$

where $\mathrm{M}_{\mathrm{C}}$ was milk output per cow $(\mathrm{kg} / \mathrm{yr}), \mathrm{AF} 2$ was the economic AF between milk output and liveweight export and D was on-farm diesel use (L/ha). Three clusters were found to be appropriate grouping by Kmeans clustering with the 3 indicators (Table 2), as grouping into 2 clusters resulted in the difference not being significant, and grouping into 4 clusters resulted in one cluster having only 1 farm. The ranking of $\mathrm{CF}$ was cluster $3<$ cluster $1<$ cluster 2 , and significant differences were found between clusters 1 and $3(P<0.05)$ and 2 and $3(P=0.002)$, but not between clusters 1 and $2(P>0.05)$. The largest difference among clusters was the white clover seed density (kilograms of seeds per hectare of farm), where cluster 2 was $275 \%$ higher than cluster 1 , followed by milk output per cow, where the cluster 3 was $42 \%$ higher than cluster 2 . Large differences were also found in fertilizer use, electricity per unit milk, and diesel per hectare, whereas the $2 \mathrm{AF}$ (AF1 and AF2) were similar across the 3 clusters.

If using alternative allocation (AF3 instead of AF1 and AF2), the average $\mathrm{CF}$ was increased to $1.22 \mathrm{~kg}$ of $\mathrm{CO}_{2} \mathrm{Eq} / \mathrm{kg}$ of ECM. Similar indicators (milk output per cow and AF3) were found in the stepwise regression to determine milk $\mathrm{CF}$ : 
Table 1. Overview of characteristics of the 18 farms in the survey ${ }^{1}$

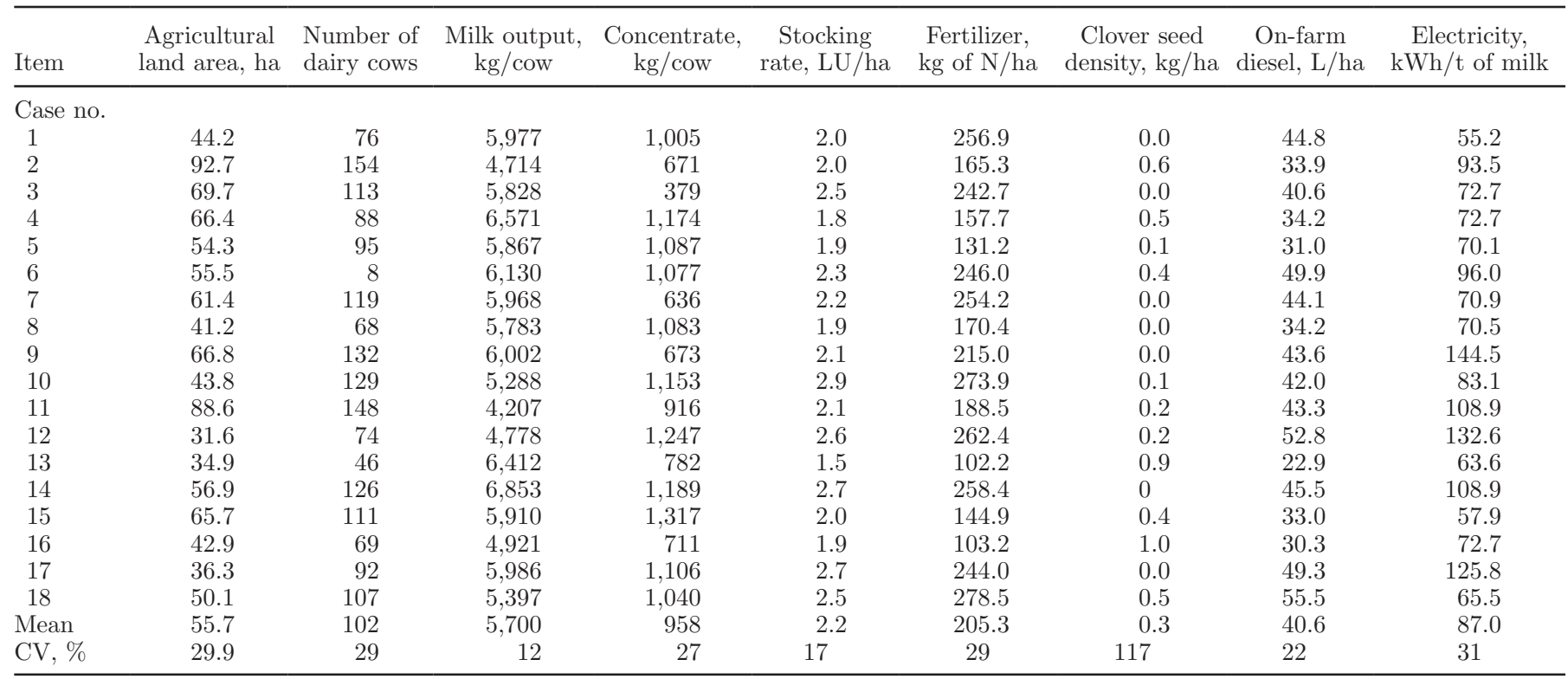

${ }^{1} \mathrm{LU}=$ livestock unit.

$$
\begin{gathered}
\text { Milk CF }=1.14-1.69 \times 10^{-4} \mathrm{M}_{\mathrm{C}} \\
+1.29 \times \text { AF3 }\left(\mathrm{R}^{2}=0.62\right) .
\end{gathered}
$$

Due to lower correlation coefficient and similar indicators, K-means clustering was not performed with AF3.

\section{Land Use}

The average land use was $1.22 \pm 0.05 \mathrm{~m}^{2} / \mathrm{kg}$ of ECM, $83 \%$ of which was on farm. On average, farms used 55.7 ha on farm (larger than the national average of 48 ha; Hennessy et al., 2011), and 10.7 ha off farm for concentrate feed and purchased silage and straw. The contributions to land use were dominated by the on-farm grassland (83\%), followed by prefarm land for concentrate (14\%) and purchased silage and straw $(3 \%)$. Fertilizer $\mathrm{N}$ rate $(\mathrm{F})$, milk output per cow $\left(\mathrm{M}_{\mathrm{C}}\right)$ and AF2 (the economic AF between milk output and liveweight export) were found by stepwise regression to be possible indicators of land use:

$$
\begin{aligned}
& \text { Land use }=1.25-2.47 \times 10^{-3} \mathrm{~F}-1.45 \\
& \times 10^{-4} \mathrm{M}_{\mathrm{c}}+1.50 \times \mathrm{AF} 2\left(\mathrm{R}^{2}=0.86\right)
\end{aligned}
$$

The same clusters were found by K-means clustering with the 3 possible indicators (Table 2 ) but the ranking by land use was cluster $1<$ cluster $3<$ cluster 2 , and a significant difference was found between clusters 1 and $2(P=0.01)$ and 2 and $3(P<0.05)$, but not between clusters 1 and $3(P>0.05)$.
If using alternative allocation (AF3 instead of AF1 and AF2), the land use was increased to $1.23 \mathrm{~m}^{2} / \mathrm{kg}$ of ECM. Only white clover seed density (WC; kilograms of seeds per hectare of farm) was found in the stepwise regression to determine the land use:

$$
\text { Land use }=1.11+0.458 \times \mathrm{WC}\left(\mathrm{R}^{2}=0.48\right) . \quad[14]
$$

Due to lower correlation coefficient and similar indicators, K-means clustering was not performed with AF3.

\section{DISCUSSION}

\section{Modeling Assumptions}

Effect of Allocation on $\boldsymbol{C F}$. In the 2-step allocation, AF1 assumes that the contribution of the dairy unit was proportionate to the dairy LU, and AF2 assumes that the contribution of milk was proportionate to the milk sales. A potential shortcoming with AF1 lies with concentrate feed because it was possible on most farms that the dairy cows consumed the majority of this feed. The average AF1 was 0.94 over the 18 farms, but if recalculated assuming the dairy unit consumed $100 \%$ of the concentrates (which indicates the magnitude of uncertainty), this would only increase the average CF by $0.7 \%$. Scope for future research exists to compare allocating by $\mathrm{NE}$ consumption rather than by LU, which was based on excreted N, but for practical purposes, the excreted $\mathrm{N}$ approach is more readily deployed. In the alternative allocation of AF3, the assumption was that the contribution of milk was 


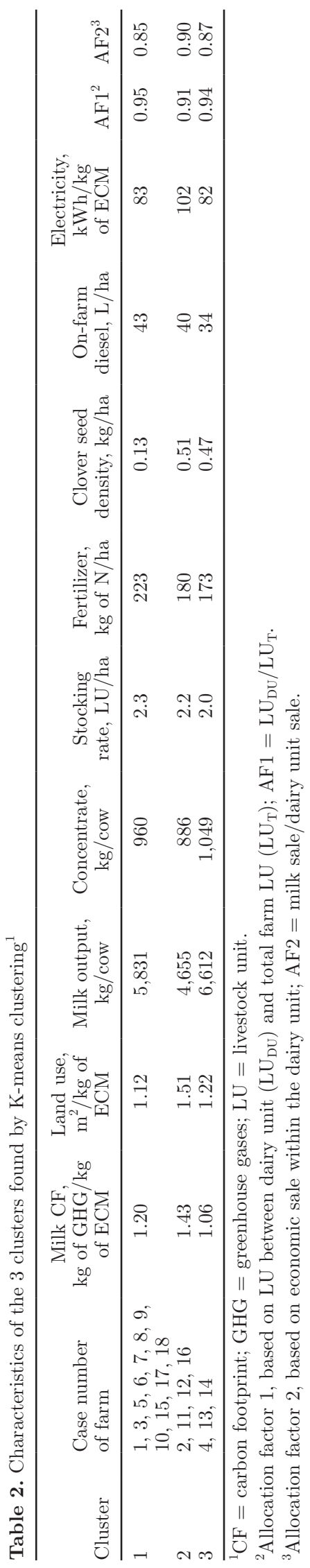

proportionate to the milk sales, which is subject to market fluctuation and, thus, may not necessarily reflect the distribution of environmental burden.

Effect of Allocation on Land Use. For the land use, using AF1 to estimate on-farm land area assumes that the stocking rate for dairy herd and other animals were the same, which was probably not the case. Using AF1 for prefarm land, which was used to provide concentrate, silage, and straw, the same assumption of an equal distribution among all animals existed as in milk CF.

Manure Management. Manure spreading contributed about $4 \%$ to the milk $\mathrm{CF}$ due to $\mathrm{N}_{2} \mathrm{O}$ emissions. The amount of nitrogen spread in the slurry was based on the assumption of a standard nitrogen content (S.I. No. 610; European Communities, 2010) multiplied by the volume of slurry spread (recorded by the farmer), whereas the estimated amount of nitrogen stored in the slurry before spreading was based on the standard nitrogen excretion of each type of animal (S.I. No. 610; European Communities, 2010). Comparison of these 2 estimates led to a mass imbalance between storage and spreading, because the nitrogen stored was found to be less than the nitrogen spread, which was not possible. This result indicated that the assumed standard nitrogen content of slurry was probably overestimated due to dilution during storage by yard wash water, yard runoff, and direct rainfall into the slurry tank. When recalculated using the estimate of nitrogen stored, the average milk CF was reduced by $2.2 \%$ (with a reduction range of 0.3 to $5.7 \%$ ). Better estimation of slurry nitrogen content in the future is recommended.

\section{Interpretation}

Geographical Distribution of Contributors. Onfarm activity accounted for around $80 \%$ of CF, which was higher than estimates for comparable production systems in the Netherlands at $50 \%$ (Thomassen et al., 2008), close to grass-based research farms in Ireland at $76 \%$ (O'Brien et al., 2012), but lower than Denmark at $87.5 \%$ (Kristensen et al., 2011). The systems in the Netherlands (Thomassen et al., 2008) were more reliant on imported feed and indoor feeding of maize and grass silage; therefore, the energy supply to animal tended to be through a longer feed chain with far more bought-in components. The case in Demark (Kristensen et al., 2011) had a greater proportion of roughage grown on farm. In the current study, the $20 \%$ of CF that was off farm was predominantly generated beyond the territorial limits of Ireland because in this specific instance, there was no fertilizer or fuel production in Ireland (McGettigan et al., 2010), and the majority of animal concentrate feed was imported (based on calculation 

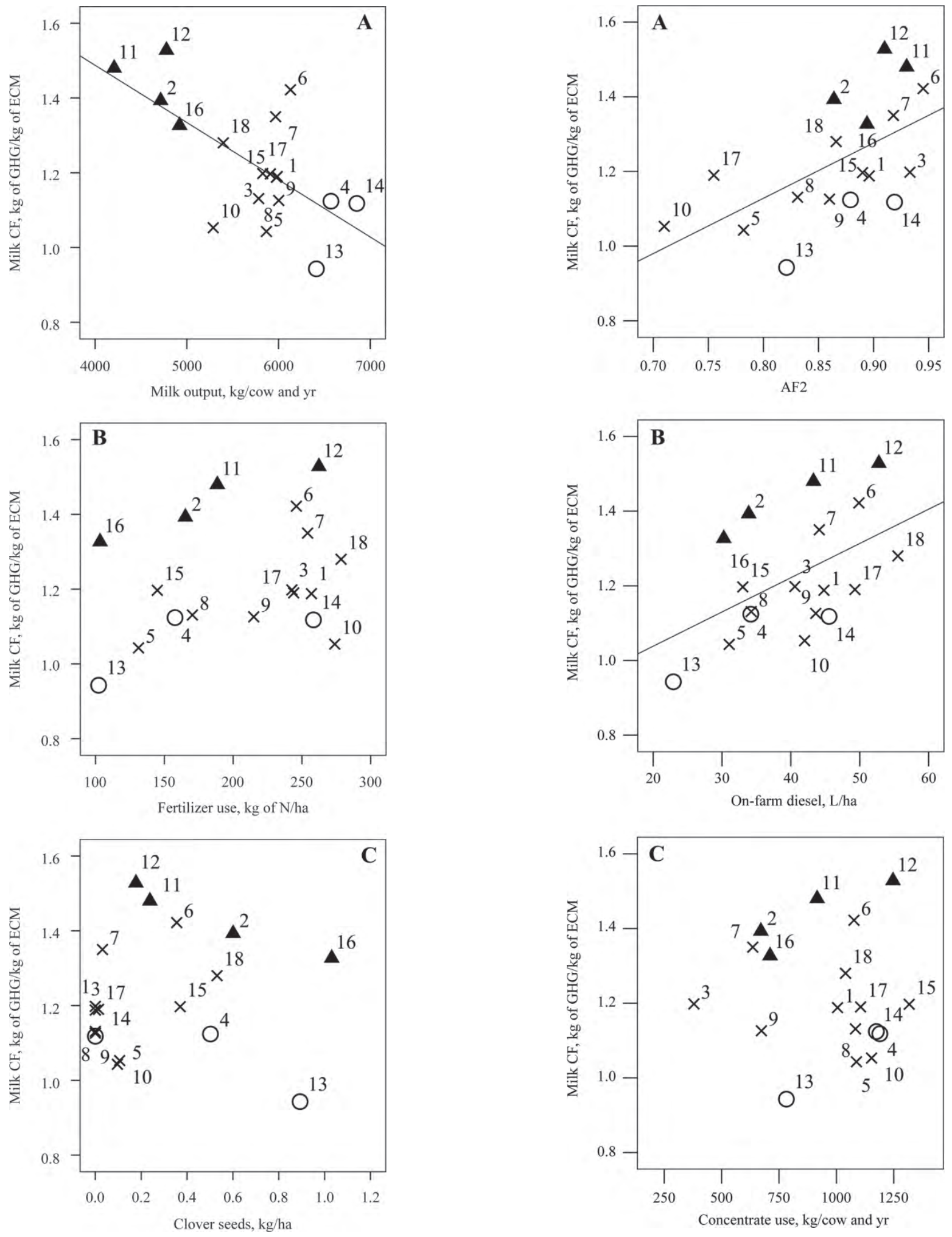

Figure 1. A: correlation between milk output per cow and milk carbon footprint $(\mathrm{CF} ; P<0.05, \mathrm{r}=-0.66)$; $\mathrm{B}$ : correlation between fertilizer nitrogen rate and milk CF $(P>0.05)$; C: correlation between clover seed density and milk CF $(P>0.05)$. Cases are numbered according to Table 1 and grouped into clusters $1(\times), 2(\mathbf{\Lambda})$, and $3(\bigcirc)$. $\mathrm{GHG}=$ greenhouse gases.

Figure 2. A: correlation between allocation factor 2 (AF2) and milk carbon footprint $(\mathrm{CF} ; P<0.05, \mathrm{r}=0.60)$; B: correlation between on-farm diesel use and milk $\mathrm{CF}(P<0.05, \mathrm{r}=0.50)$; $\mathrm{C}$ : correlation between concentrate use and milk CF $(P>0.05)$. Cases are numbered according to Table 1 and grouped into clusters $1(\times), 2(\mathbf{\Lambda})$, and $3(\bigcirc)$. $\mathrm{GHG}=$ greenhouse gases. 

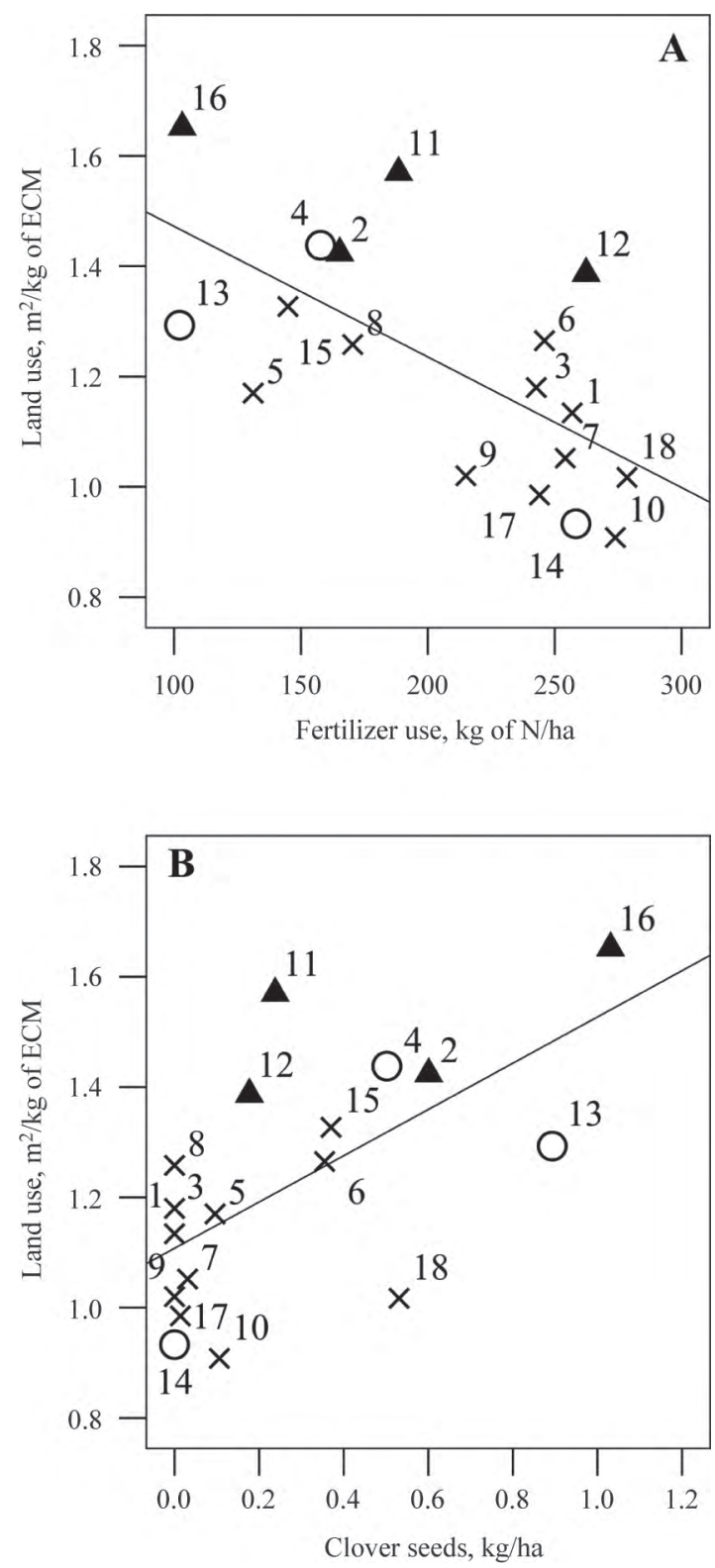

Figure 3. A: correlation between fertilizer nitrogen rate and land use $(P<0.05, \mathrm{r}=-0.66)$; B: correlation between clover seed density and land use $(P<0.05, \mathrm{r}=0.62)$. Cases are numbered according to Table 1 and grouped into clusters $1(\times), 2(\mathbf{\Lambda})$, and $3(\bigcirc)$.

from Department of Agriculture, Fisheries and Food, 2011).

On-farm land accounted for $83 \%$ of overall land use, which was closely related to on-farm activities such as the negative correlations with fertilizer use $(P<$ 0.05 ), stocking rate, and milk output per cow (both $P<0.05)$, and positive correlation with white clover seeds per hectare $(P<0.05)$, indicating greater land efficiency with intensification.

Impact of Tactics on Milk CF. Milk output per cow was the basis for estimating enteric fermentation,
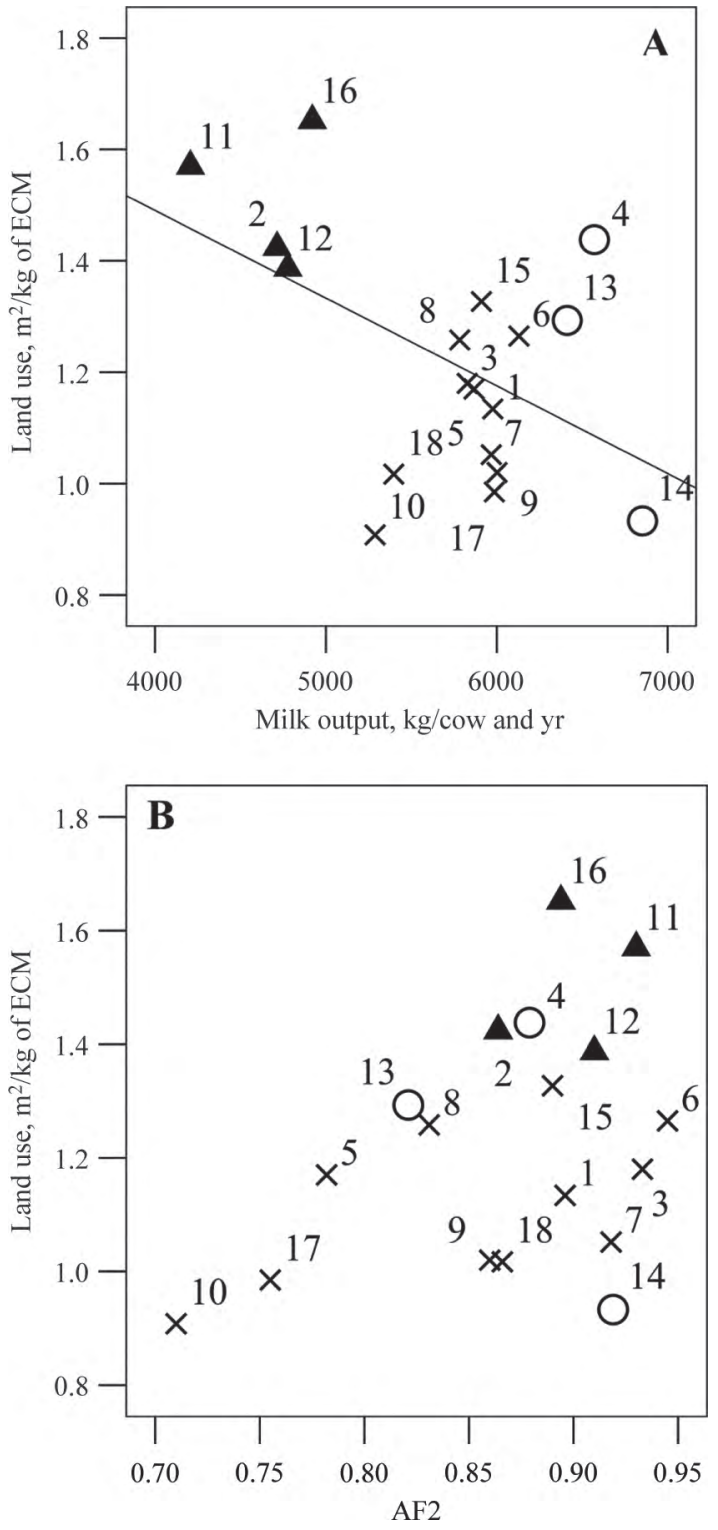

Figure 4. A: correlation between milk output per cow and land use $(P<0.05, \mathrm{r}=-0.50)$; B: correlation between allocation factor $2(\mathrm{AF} 2)$ and land use $(P>0.05)$. Cases are numbered according to Table 1 and grouped into clusters $1(\times), 2(\mathbf{\Delta})$, and $3(\bigcirc)$.

which contributed to about $43 \%$ to the $\mathrm{CF}$ in this study. It is also an indicator of the conversion efficiency of feed, which determines the efficiency of the production system. It is thus not surprising that milk output per cow was found to be the most important factor related to milk $\mathrm{CF}$, and distinguished the clusters (Figure $1 \mathrm{~A} ; P<0.05)$. For example, compared with cluster 3 , cluster 2 had $30 \%$ lower milk output per cow and, thus, $33 \%$ higher CF. This has also been found to be crucial for milk CF across the world, where developed countries tend to have lower $\mathrm{CF}$ due to higher productivity (FAO, 2010; Hagemann et al., 2011). However, 


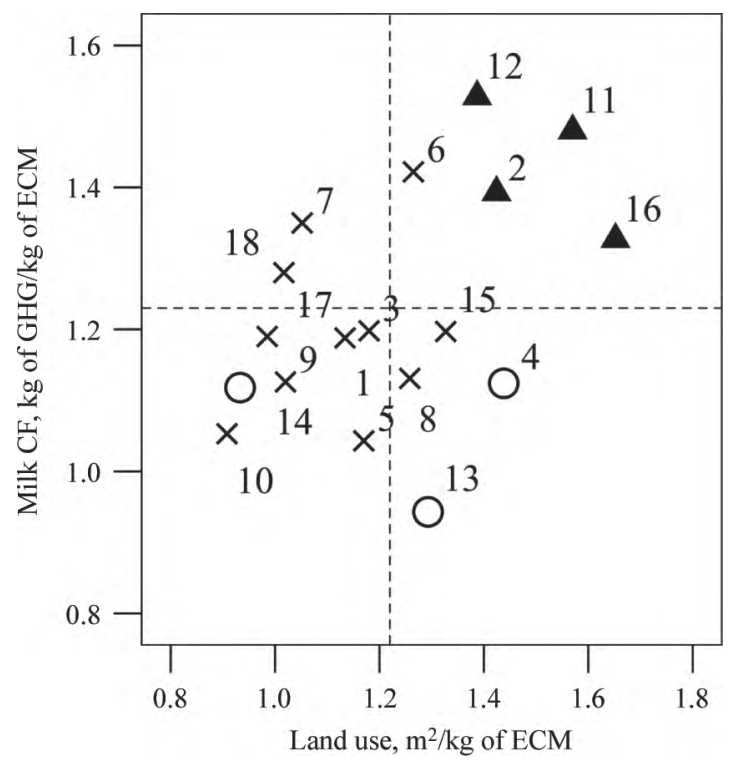

Figure 5. Correlation between land use and milk carbon footprint $(\mathrm{CF} ; P>0.05)$. Dashed lines indicate the average of milk CF $(1.23 \mathrm{~kg}$ of $\mathrm{CO}_{2} \mathrm{Eq} / \mathrm{kg}$ of ECM) and land use $\left(1.22 \mathrm{~m}^{2} / \mathrm{kg}\right.$ of ECM). Cases are numbered according to Table 1 and grouped into clusters $1(\times), 2(\boldsymbol{\Lambda})$ and $3(\bigcirc)$. GHG = greenhouse gases.

the trend was not obvious among the 11 cases of cluster 1 , where a $4 \%$ increase in milk output resulted in a $36 \%$ increase in the $\mathrm{CF}$ (Figure 1A, cases 5 and 6 ), and $10 \%$ less milk output resulted in a $1 \%$ increase in the $\mathrm{CF}$ (Figure 1A, cases 10 and 5). This suggests that other tactics (discussed below) also played a role in determining the milk CF.

The fertilizer $\mathrm{N}$ rate of the 18 farms was found to be $53 \%$ higher than the national average for 2008 (Lalor et al., 2010). Increased fertilizer $\mathrm{N}$ rate tended to increase the milk CF (Figure 1B; $P>0.05$ ), and increased white clover seed density appeared to reduce CF (Figure 1C; $P>0.05$ ). In clusters 2 and 3 , farmers with higher fertilizer $\mathrm{N}$ rate tended to have lower white clover seed rate, which corresponded to higher milk CF (Figure 1B, 1C). High fertilizer $\mathrm{N}$ rate often results in higher surpluses of $\mathrm{N}$, which was found to be an indicator of CF by Schils et al. (2006). Research carried out at a research farm also found that a white clover-based system could reduce milk CF by 11 to $23 \%$ compared with a fertilizer-based system (Yan et al., 2013). The gap in CF between cluster 2 and 3 can be explained by the milk output per cow. If the farms in cluster 2 were to improve milk output per cow while keeping other tactics unchanged, the $\mathrm{CF}$ would improve. The trend in CF was not so clear among cases in cluster 1 due to the apparent contradiction between fertilizer $\mathrm{N}$ rate and the white clover seed density. For example, case 18 reseeded clover at moderate rate, whereas case
8 did not (Figure 1C), but case 18 used over $278 \mathrm{~kg}$ of fertilizer $\mathrm{N} /$ ha, $63 \%$ higher than case 8 (Figure 1B). Research has shown that at $180 \mathrm{~kg}$ of $\mathrm{N} / \mathrm{ha}$, grass will dominate white clover in mixed swards (Humphreys et al., 2008) so the situation of case 18 implied poor clover management. To gain the benefits of white clover management in terms of lower milk $\mathrm{CF}$, fertilizer $\mathrm{N}$ should optimized.

Whereas AF1 reflected the degree of specialization of the dairy farm where highly specialized dairy farms had high AF1 values, AF2 was more unclear and reflected market fluctuation. In this study, average AF1 was greater but the variation was smaller than that of $\mathrm{AF} 2($ mean $=0.94$ and $0.87 ; \mathrm{CV}=4$ and $7 \%$, respectively), implying a difference in farm sales strategies. For example, 3 farms (cases 10, 17, and 5) had much higher cow sales than the rest (means $=16$ and $7 \%$, respectively), part of which was from selling milking cows, resulting in a very low AF2 value to milk. The $\mathrm{AF} 2$ was an influential factor on $\mathrm{CF}$, whereas $\mathrm{AF} 1$ was less relevant (Figure 2A). Cluster 2 and 3 had similar AF2 (>0.82) between milk and liveweight export, albeit with very different milk output per cow, whereas cluster 1 had AF2 across the whole range (Figure 2A). The $22 \%$ higher AF2 in case 6 could explain the difference in $\mathrm{CF}$ between cases 5 and 6 , and the $10 \%$ higher AF2 in case 5 could explain the similar CF between cases 5 and 10.

On-farm diesel use per hectare reflected the stocking density, as diesel was mainly used for fertilizer spreading and forage harvesting. On-farm diesel use was correlated with stocking density and fertilizer $\mathrm{N}$ use (both $P<0.05)$ and was found to be an influential factor on $\mathrm{CF}$ (Figure 2B). As on-farm diesel use increased, so did the milk $\mathrm{CF}$, but little distinction existed between the 3 clusters. For example, individual cases from different clusters may have similar diesel use per hectare but very different CF (e.g., Figure 2B, cases 11 and 10 ), and within the same cluster the opposite existed (e.g., Figure 2B, cases 17 and 15). It can be seen that on-farm diesel use indicated the production status but may not determine the milk $\mathrm{CF}$ on its own.

In addition to the above tactics that were found to be influential factors for $\mathrm{CF}$, the effect of concentrate feed was also important. In an ideal low-cost, grassbased, rotational grazing dairy system, concentrate is only provided as supplements to dairy cows during lactation and calves during the early stage of life. High concentrate feeding in pasture-based grazing systems generally implies deficit of on-farm feed supply due to high stocking rate or poor grass growth, both of which can lead to increased CF (Casey and Holden, 2005b). In the current study, no clear relationship was found 
between concentrate feeding and milk CF (Figure 2C). Up to a 3.5-fold difference in concentrate was fed to gain a similar milk output per cow and milk CF (Figure $1 \mathrm{~A}$ and Figure $2 \mathrm{C}$, cases 15 and 3), suggesting large potential of improvement. The main reason for the poor relationship between concentrate and milk CF may be the inefficient feed management (i.e., greater use of concentrate in some instances to balance feed supply), and different milk production response of cow breeds to concentrate feed rates (O'Brien et al., 2010), and herd health factors may also have effect.

Impact of Tactics on Land Use. Increased fertilizer $\mathrm{N}$ rate was found be the most important factor to reduce land use (Figure 3A; $P<0.05$ ), whereas increased clover seed density appeared to increase land use (Figure 3B; $P<0.05$ ). This was mainly due to the effect on the on-farm land use, as higher fertilizer rate resulted in higher stocking rate $(P<0.05)$ and less land requirement per unit milk production, whereas prefarm land use was not affected $(P>0.05)$.

Milk output per cow was found to be the second important factor in affecting land use (Figure 4A; $P$ $<0.05)$. As milk output per cow increased, land use tended to decrease, but it was the cluster with moderate milk output per cow (cluster 1) that had the lowest average land use (Table 2; Figure 4A). As on-farm grassland was the dominant contributor, stocking rate and milk output per cow determined the overall land use per unit milk, both of which reduced on-farm land use per unit milk, as can be seen from cluster 1 and 2 . One notable outlier was found in case 14 (cluster 3), which had both high milk output per cow and stocking rate, resulting in the second lowest land use.

Although AF2 was found to influence land use, its effect was not obvious (Figure 4B). For example, case 10 and 14 had very similar fertilizer $\mathrm{N}$ rates (Figure 1B) and large differences in AF2, yet little difference in land use (Figure 4B).

\section{Implications on Mitigation Strategies of CF and Land Use}

The positive relationship between milk CF and land use found by Casey and Holden (2005a) was detected in this study but it was not significant (Figure 5). This is understandable, as the indicators address different aspects of milk production: CF tends to reflect the feed conversion efficiency by animals and nutrient use efficiency, whereas land use reflects the reliance of milk production on the amount and type of feed. Improving milk output per cow without significantly increasing concentrate feeding, and optimizing fertilizer use and clover management can be seen as a combination of mitigation strategies for milk $\mathrm{CF}$ without affecting land use. Future studies need to focus on the feasibility and cost-effectiveness of mitigation approaches considering the global context of market demand and the specifics of farm tactical management. Better estimation of slurry nitrogen content is also recommended.

\section{CONCLUSIONS}

A large variation in farm tactical management was found, but the CF of milk production between farms only varied by a coefficient of variation of $13 \%$, and of land use by $18 \%$. Milk output per cow was found to be the most influential factor determining CF. Fertilizer $\mathrm{N}$ use was the most influential factor determining land use. A farm with a low CF did not always have low land use and vice versa.

\section{ACKNOWLEDGMENTS}

The authors thank the farms for their cooperation in the survey, Joseph Kirk and Andy Boland (Teagasc Moorepark, Fermoy, Co. Cork, Ireland) for their great effort in collecting the data, and partial funding from the European Research and Development Fund (ERDF) via Interreg IVB project O96D (Dairyman).

\section{REFERENCES}

Basset-Mens, C., S. Ledgard, and M. Boyes. 2009. Eco-efficiency of intensification scenarios for milk production in New Zealand. Ecol. Econ. 68:1615-1625.

Casey, J. W., and N. M. Holden. 2005a. The relationship between greenhouse gas emissions and the intensity of milk production in Ireland. J. Environ. Qual. 34:429-436.

Casey, J. W., and N. M. Holden. 2005b. Analysis of greenhouse gas emissions from the average Irish milk production system. Agric. Syst. 86:97-114.

Cederberg, C., and B. Mattsson. 2000. Life cycle assessment of milk production-A comparison of conventional and organic farming. J. Clean. Prod. 8:49-60.

Cederberg, C., U. M. Persson, K. Neovius, S. Molander, and R. Clift. 2011. Including carbon emissions from deforestation in the carbon footprint of Brazilian beef. Environ. Sci. Technol. 45:1773-1779.

CSO (Central Statistics Office). 2010a. Intake of cows milk by creameries and pasteurisers. Accessed Mar. 28, 2013. http://www.cso. ie/px/pxeirestat/Statire/SelectVarVal/Define.asp?maintable $=$ AK M01\&PLanguage $=0$.

CSO (Central Statistics Office). 2010b. Farm Animals in December by type of animal and year (2005-2012). Accessed Mar. 28, 2013. http://www.cso.ie/px/pxeirestat/Statire/SelectVarVal/Define.asp $?$ maintable $=$ AAA06\&PLanguage $=0$.

CSO (Central Statistics Office). 2010c. Number of livestock in June by type of animal, year and region (1991-2009). Accessed Mar. 28, 2013. http://www.cso.ie/px/pxeirestat/Statire/SelectVarVal/ Define.asp maintable $=$ AAA01\&PLanguage $=0$.

Cederberg, C., and M. Stadig. 2003. System expansion and allocation in life cycle assessment of milk and beef production. Int. J. Life Cycle Assess. 8:350-356.

Del Prado, A., T. Misselbrook, D. Chadwick, A. Hopkins, R. J. Dewhurst, P. Davison, A. Butler, J. Schröder, and D. Scholefield. 2011. SIMS(DAIRY): A modelling framework to identify sustain- 
able dairy farms in the UK. Framework description and test for organic systems and $\mathrm{N}$ fertiliser optimisation. Sci. Total Environ. 409:3993-4009.

Department of Agriculture, Fisheries and Food. 2011. Annual review \& outlook for agriculture, fisheries \& food 2010/2011. Department of Agriculture, Fisheries and Food, Dublin, Ireland. Accessed Aug. 15, 2012. http://www.agriculture.gov.ie/media/migration/publications/2011/AR02011.pdf.

Ecoinvent. 2011. Ecoinvent Data v2.2. Swiss Centre of Life Cycle Inventories, Zurich, Switzerland.

European Communities. 2010. European Communities (good agricultural practice for protection of waters) regulations 2010. Statutory Instruments (S.I.) No. 610. Government Publications Sales Office, Sun Alliance House, Dublin, Ireland.

FAO (Food and Agriculture Organization of the United Nations). 2010. Greenhouse gas emissions from the dairy sector: A life cycle assessment. FAO, Rome, Italy.

Flysjö, A., C. Cederberg, M. Henriksson, and S. Ledgard. 2011. How does co-product handling affect the carbon footprint of milk? Case study of milk production in New Zealand and Sweden. Int. J. Life Cycle Assess. 16:420-430.

Flysjö, A., C. Cederberg, M. Henriksson, and S. Ledgard. 2012. The interaction between milk and beef production and emissions from land use change - Critical considerations in life cycle assessment and carbon footprint studies of milk. J. Clean. Prod. 28:134-142.

Gerber, P., T. Vellinga, C. Opio, B. Henderson, and H. Steinfeld. 2010. Greenhouse Gas Emissions from the Dairy Sector, a Life Cycle Assessment. Food and Agriculture Organization of the United Nations, Animal Production and Health Division, Rome, Italy.

Guinée, J. B., M. Gorrée, R. Heijungs, G. Huppes, R. Kleijn, A. de Koning, L. van Oers, A. W. Sleeswijk, S. Suh, H. A. Udo de Haes, H. de Brujin, R. van Duin, and M. A. J. Huijbregts. 2002. Handbook on Life Cycle Assessment: Operational Guide to the ISO Standards. Kluwer Academic Publishers, Dordrecht, the Netherlands.

Hagemann, M., T. Hemme, A. Ndambi, O. Alqaisi, and M. N. Sultana. 2011. Benchmarking of greenhouse gas emissions of bovine milk production systems for 38 countries. Anim. Feed Sci. Technol. 166:46-58.

Hennessy, T., B. Moran, A. Kinsella, and G. Quinlan. 2011. National Farm Survey 2010. Agricultural Economics \& Farm Surveys Department, Teagasc Athenry, Co. Galway, Ireland. Accessed Aug. 15, 2012. http://www.teagasc.ie/publications/2011/1016/NFS10. pdf.

Henriksson, M., A. Flysjö, C. Cederberg, and C. Swensson. 2011. Variation in carbon footprint of milk due to management differences between Swedish dairy farms. Animal 5:1474-1484.

Humbert, S., V. Rossi, M. Margni, O. Jolliet, and Y. Loerincik. 2009 Life cycle assessment of two baby food packaging alternatives: Glass jars vs. plastic pots. Int. J. Life Cycle Assess. 14:95-106.

Humphreys, J., E. Mihailescu, and I. A. Casey. 2012. An economic comparison of systems of dairy production based on N-fertilized grass and grass-white clover grassland in a moist maritime environment. Grass Forage Sci. 67:519-525. http://dx.doi.org/10.1111/ j.1365-2494.2012.00871.x.

Humphreys, J., K. O'Connell, and I. A. Casey. 2008. Nitrogen flows and balances in four grassland-based systems of dairy production on a clay-loam soil in a moist temperate climate. Grass Forage Sci. $63: 467-480$.

IDF (International Dairy Federation). 2009. Environmental/ecological impact of the dairy sector. Bulletin of the International Dairy Federation 436/2009. IDF, Brussels, Belgium.

IDF (International Dairy Federation). 2010. A common carbon footprint approach for dairy. The IDF guide to standard lifecycle assessment methodology for the dairy sector. Bulletin of the International Dairy Federation 445/2010. IDF, Brussels, Belgium.

IPCC (Intergovernmental Panel on Climate Change). 2006. 2006 IPCC Guidelines for National Greenhouse Gas Inventories. Vol. 4, Agriculture, Forestry and other Land Use. Institute for Global Environmental Strategies (IGES), Hayama, Japan.
ISO (International Organization for Standardization). 2006. Environmental management-Life cycle assessment-Principles and framework. EN ISO 14040. ISO, Geneva, Switzerland.

Kristensen, T., L. Mogensen, M. T. Knudsen, and J. E. Hermansen. 2011. Effect of production system and farming strategy on greenhouse gas emissions from commercial dairy farms in a life cycle approach. Livest. Sci. 140:136-148.

Lalor, S. T. J., B. S. Coulter, G. Quinlan, and L. Connolly. 2010. A survey of fertilizer use in Ireland from 2004-2008 for grassland and arable crops. Teagasc Johnstown Castle Environment Research Centre, Wexford, Ireland. Accessed Aug. 15, 2012. http://www. teagasc.ie/publications/view_publication.aspx?publicationID $=13$.

Luo, Z., E. Wang, and O. J. Sun. 2010. Can no-tillage stimulate carbon sequestration in agricultural soils? A meta-analysis of paired experiments. Agric. Ecosyst. Environ. 139:224-231.

McGettigan, M., P. Duffy, B. Hyde, E. Hanley, P. O'Brien, J. Ponzi, and K. Black. 2010. National inventory report 2010. Greenhouse gas emissions 1990-2008 reported to the United Nations Framework Convention on Climate Change. Environmental Protection Agency, Johnstown Castle Estate, Co. Wexford, Ireland. Accessed Aug. 15, 2012. http://coe.epa.ie/ghg/nirs/NIR_2010_IEv1.2.pdf.

Nemecek T., T. Kägi, and S. Blaser. 2007. Life Cycle Inventories of Agricultural Production Systems. Final report ecoinvent v2.0 No.15. Swiss Centre for Life Cycle Inventories, Dübendorf, Switzerland.

Nilsson, K., A. Flysjö, J. Davis, S. Sim, N. Unger, and S. Bell. 2010. Comparative life cycle assessment of margarine and butter consumed in the UK, Germany and France. Int. J. Life Cycle Assess. 15:916-926.

O'Brien, D., L. Shalloo, C. Grainger, F. Buckley, B. Horan, and M. Wallace. 2010. The influence of strain of Holstein-Friesian cow and feeding system on greenhouse gas emissions from pastoral dairy farms. J. Dairy Sci. 93:3390-3402.

O'Brien, D., L. Shalloo, J. Patton, F. Buckley, C. Grainger, and M. Wallace. 2012. A life cycle assessment of seasonal grass-based and confinement dairy farms. Agric. Syst. 107:33-46.

O'Mara, F. 2006. Climate change-Development of emission factors for the Irish cattle herd. 2000-LS-5.1.1-M1 special report. Environmental Protection Agency, Johnstown Castle, Co. Wexford, Ireland.

PASW Statistics 18. 2012. IBM SPSS Statistics software. Accessed Sep. 16, 2011. http://www-01.ibm.com/software/analytics/spss/.

Schils, R. L. M., A. Verhagen, H. F. M. Aarts, P. J. Kuikman, and L. B. J. Šebek. 2006. Effect of improved nitrogen management on greenhouse gas emissions from intensive dairy systems in the Netherlands. Glob. Change Biol. 12:382-391.

SEAI (Sustainable Energy Authority of Ireland). 2010. Electricity emission factors 1990-2010. Accessed Nov. 28, 2012. http://www. seai.ie/Publications/Statistics_Publications/Emission_Factors/.

Shalloo, L., P. Dillon, M. Rath, and M. Wallace. 2004. Description and validation of the Moorepark Dairy System Model. J. Dairy Sci. $87: 1945-1959$.

Sjaunja, L. O., L. Baevre, L. Junkkarinen, J. Pedersen, and J. Setälä. 1990. A Nordic proposal for an energy corrected milk (ECM) formula. Page 192 in 27th Session of the International Commission for Breeding and Productivity of Milk Animals, Paris. Wageningen Academic Publishers, Wageningen, the Netherlands.

Solomon, S., D. Qin, M. Manning, Z. Chen, M. Marquis, K. B. Averyt, M. Tignor, and H. L. Miller, editors. 2007. Contribution of Working Group I to the Fourth Assessment Report of the Intergovernmental Panel on Climate Change. Cambridge University Press, Cambridge, UK and New York, NY. Accessed Aug. 15, 2012. http://www.ipcc.ch/publications_and_data/ar4/wg1/en/ ch2s2-10-2.html.

Steinfeld, H., P. Gerber, T. Wassenaar, V. Castel, M. Rosales, and C. de Haan. 2006. Livestock's Long Shadow. Environmental Issues and Options. Food and Agriculture Organization of the United Nations, Animal Production and Health Division, Rome, Italy.

Teagasc. 2011. eProfit Monitor Farm Analysis \& Benchmarking. Teagasc Oak Park, Carlow, Ireland. 
Thomassen, M. A., M. A. Dolman, K. J. van Calker, and I. J. M. de Boer. 2009. Relating life cycle assessment indicators to gross value added for Dutch dairy farms. Ecol. Econ. 68:2278-2284.

Thomassen, M. A., K. J. van Calker, M. C. J. Smits, G. L. Iepema, and I. J. M. de Boer. 2008. Life cycle assessment of conventional and organic milk production in the Netherlands. Agric. Syst. 96:95-107.

van der Werf, H. M. G., J. Tzilivakis, K. Lewis, and C. Basset-Mens. 2007. Environmental impacts of farm scenarios according to five assessment methods. Agric. Ecosyst. Environ. 118:327-338.
Weiss, F., and A. Leip. 2012. Greenhouse gas emissions from the EU livestock sector: A life cycle assessment carried out with the CAPRI model. Agric. Ecosyst. Environ. 149:124-134.

Yan, M.-J., J. Humphreys, and M. N. Holden. 2011. An evaluation of life cycle assessment of European milk production. J. Environ. Manage. 92:372-379.

Yan, M.-J., J. Humphreys, and M. N. Holden. 2013. The carbon footprint of pasture based milk production: Can white clover make a difference? J. Dairy Sci. 96:857-865. 